\title{
Nitric Oxide Reduction by Carbon Monoxide over Supported Hexaruthenium Cluster Catalysts. 1. The Active Site Structure That Depends on Supporting Metal Oxide and Catalytic Reaction Conditions
}

\author{
Taketoshi Minato ${ }^{\dagger}$ Yasuo Izumi, ${ }^{*},{ }^{\dagger}$ Ken-ichi Aika, ${ }^{\dagger}$ Atsushi Ishiguro, ${ }^{\dagger}$ \\ Takayuki Nakajima,, and Yasuo Wakatsuki*," \\ Department of Environmental Chemistry and Engineering, Interdisciplinary Graduate School of Science and \\ Engineering, Tokyo Institute of Technology, 4259 Nagatsuta, Midori-ku, Yokohama 226-8502, Japan, and \\ RIKEN (The Institute of Physical and Chemical Research), 2-1, Hirosawa, Wako, Saitama 351-0198, Japan
}

Received: February 18, 2003; In Final Form: June 2, 2003

\begin{abstract}
Ruthenium site structures supported on metal oxide surfaces were designed by reacting organometallic Ru cluster $\left[\mathrm{Ru}_{6} \mathrm{C}(\mathrm{CO})_{16}\right]^{2-}$ or $\left[\mathrm{Ru}_{6}(\mathrm{CO})_{18}\right]^{2-}$ with various metal oxides, $\mathrm{TiO}_{2}, \mathrm{Al}_{2} \mathrm{O}_{3}, \mathrm{MgO}$, and $\mathrm{SiO}_{2}$. The surface $\mathrm{Ru}$ site structure, formed under various catalyst preparation and reaction conditions, was investigated by the $\mathrm{Ru}$ K-edge extended X-ray absorption fine structure (EXAFS). Samples of $\left[\mathrm{Ru}_{6} \mathrm{C}(\mathrm{CO})_{16}\right]^{2-} / \mathrm{TiO}_{2}($ anatase $)$ and $\left[\mathrm{Ru}_{6} \mathrm{C}(\mathrm{CO})_{16}\right]^{2-} / \mathrm{TiO}_{2}$ (rutile) were found to retain the original $\mathrm{Ru}_{6} \mathrm{C}$ framework when heated in the presence of $\mathrm{NO}(2.0 \mathrm{kPa})$ or $\mathrm{NO}(2.0 \mathrm{kPa})+\mathrm{CO}(2.0 \mathrm{kPa})$ at $423 \mathrm{~K}$, i.e., catalytic reaction conditions for $\mathrm{NO}$ decomposition. At $523 \mathrm{~K}$, the $\mathrm{Ru}-\mathrm{Ru}$ bonds of the $\mathrm{Ru}_{6} \mathrm{C}$ framework were cleaved by the attack of NO. In contrast, the $\mathrm{Ru}$ site became spontaneously dispersed over $\mathrm{TiO}_{2}$ (anatase). When being supported over $\mathrm{TiO}_{2}$ (mesoporous), $\mathrm{MgO}$, or $\mathrm{Al}_{2} \mathrm{O}_{3}$, the $\mathrm{Ru}_{6} \mathrm{C}$ framework split into fragments in gaseous $\mathrm{NO}$ or $\mathrm{NO}+\mathrm{CO}$ even at $423 \mathrm{~K}$. The $\mathrm{Ru}_{6}$ framework of $\left[\mathrm{Ru}_{6}(\mathrm{CO})_{18}\right]^{2-}$ was found to break easily into smaller ensembles in the presence of $\mathrm{NO}$ and/or $\mathrm{CO}$ at $423 \mathrm{~K}$ on support. Taking into consideration the realistic environments in which these catalysts will be used, we also examined the effect of water and oxygen. When water was introduced to the sample $\left[\mathrm{Ru}_{6} \mathrm{C}(\mathrm{CO})_{16}\right]^{2-} / \mathrm{TiO}_{2}$ (anatase) at $423 \mathrm{~K}$, it did not have any effects on the stabilized $\mathrm{Ru}_{6} \mathrm{C}$ framework structure. In the presence of oxygen gas, however, the Ru hexanuclear structure decomposed into isolated $\mathrm{Ru}$ cations bound to surface oxygen atoms of $\mathrm{TiO}_{2}$ (anatase).
\end{abstract}

\section{Introduction}

A variety of heterogeneous catalysts has been developed to contribute to solve environmental problems. ${ }^{1}$ These environmental catalysts often consist of complex chemical contents and in many cases it is not clear which site is responsible for the catalytic performance. Supported cluster catalysts are attractive for its unique and well-defined metal ensemble sites stabilized on surface. ${ }^{2}$ The specific catalysis for the synthesis of chemicals has been reported over supported clusters $\left[\mathrm{Ru}_{6} \mathrm{C}\right],\left[\mathrm{Ru}_{6} \mathrm{~N}\right]$, and $\left[\mathrm{Rh}_{10} \mathrm{Se}\right]$ prepared from the crystal $[\mathrm{PPN}]_{2}\left[\mathrm{Ru}_{6} \mathrm{C}(\mathrm{CO})_{16}\right](\mathbf{1}, \mathrm{PPN}$ $\left.=\left(\mathrm{PPh}_{3}\right)_{2} \mathrm{~N}\right),[\mathrm{PPN}]\left[\mathrm{Ru}_{6} \mathrm{~N}(\mathrm{CO})_{16}\right]$, and $[\mathrm{PPN}]_{2}\left[\mathrm{Rh}_{10} \mathrm{Se}(\mathrm{CO})_{22}\right]$ on $\mathrm{MgO}, \mathrm{La}_{2} \mathrm{O}_{3}, \mathrm{SiO}_{2}, \mathrm{Al}_{2} \mathrm{O}_{3}, \mathrm{TiO}_{2}$, etc. ${ }^{3-6}$ The relationship of the precious metal site structure and its specific catalytic performance was clarified. For example, supported $\left[\mathrm{Ru}_{6} \mathrm{C}\right] / \mathrm{TiO}_{2}$ catalysts exhibited selective oxygenate (formaldehyde, methanol, and dimethyl ether) synthesis starting from $\mathrm{CO}+\mathrm{H}_{2}$. The hexanuclear ruthenium unit was retained during the catalytic reaction and reversible cluster framework expansion/contraction was observed by the introduction/evacuation of $\mathrm{CO}+\mathrm{H}_{2} \cdot{ }^{3,4}$ The carbido carbon inside stabilized the $\mathrm{Ru}_{6}$ framework from inside and played a role of the center of "chemical bond spring". 4 The supported $\left[\mathrm{Rh}_{10} \mathrm{Se}\right] / \mathrm{TiO}_{2}$ catalysts showed specific high reactivity for the catalytic ethanol synthesis starting from $\mathrm{CO}_{2}$ $+\mathrm{H}_{2}$. The stabilization effects of the $\mathrm{Rh}_{10}$ unit by the interstitial

*Corresponding authors. E-mail: yizumi@chemenv.titech.ac.jp and waky@ postman.riken.go.jp.

$\dagger$ Tokyo Institute of Technology.

$\doteqdot$ RIKEN.
Se atom were reported on the basis of the Se and Rh K-edge XAFS (X-ray absorption fine structure) analyses. ${ }^{6}$

In general, catalytic decomposition of nitric oxide (NO) is a structure sensitive reaction. ${ }^{2}$ It has been recognized that the catalytic performance (conversion and selectivity) is strongly influenced by the morphology (size and shape) of supported metal. The adsorption and catalytic decomposition of NO over metal cluster catalysts have been reported. ${ }^{7-9}$ Palladium cluster catalysts in H-ZSM-5 exhibited high NO conversion $(85.0 \%)$ to $\mathrm{N}_{2}$ in the $\mathrm{NO}+\mathrm{CH}_{4}$ reaction. The correlation between its catalytic performance and the morphology of $\mathrm{Pd}$ species was reported by XAFS analyses. $\mathrm{Pd}^{2+}$ ions on acidic sites were reported to be catalytically active in the presence of $\mathrm{O}_{2}{ }^{7}$ Supported $\left[\mathrm{Pt}_{12}(\mathrm{CO})_{24}\right]^{2-} / \mathrm{NaY}$ and $\left[\mathrm{Pt}_{9}(\mathrm{CO})_{18}\right]^{2-} / \mathrm{NaY}$ catalysts showed activity 11-14 times higher compared to the case of conventional $\mathrm{Pt} / \mathrm{Al}_{2} \mathrm{O}_{3}$ catalysts for the $\mathrm{NO}+\mathrm{CO}$ reaction. ${ }^{8}$ An intact $\mathrm{Pt}_{12}$ or $\mathrm{Pt}_{9}$ cluster framework inside the zeolite cage was suggested to be the responsible site for the catalysis. ${ }^{9}$

Although ruthenium is one of the most reactive novel metals ( $\mathrm{Co}, \mathrm{Ru}, \mathrm{Rh}, \mathrm{Pd}, \mathrm{Pt}$ ) for the NO decomposition, only a little has been reported about the effects of $\mathrm{Ru}$ morphology on the catalytic performance of $\mathrm{NO}$ decomposition. At the atmospheric gas pressure conditions of $\mathrm{NO}(0.5 \%)+\mathrm{CO}(2.0 \%)$ at $423-$ $523 \mathrm{~K}$, the conversion to $\mathrm{N}_{2}$ was faster on $\mathrm{Ru} / \mathrm{Al}_{2} \mathrm{O}_{3}$ than in the cases on $\mathrm{Rh} / \mathrm{Al}_{2} \mathrm{O}_{3}, \mathrm{Pd} / \mathrm{Al}_{2} \mathrm{O}_{3}$, or $\mathrm{Pt} / \mathrm{Al}_{2} \mathrm{O}_{3} .{ }^{10}$ Recently, the reactions between $\mathrm{Ru}$ carbonyl clusters in solutions and polluting gases $\left(\mathrm{NO}, \mathrm{SO}_{2}\right)$ have been investigated as models of adsorption and catalytic removal of such gaseous molecules on metal 
ensemble site. ${ }^{11-13}$ Ishiguro et al. recently reported the application of cluster 1 to sulfur dioxide removal by supporting on $\mathrm{TiO}_{2} \cdot{ }^{14,15}$ Crystals of $[\mathrm{PPN}]\left[\mathrm{Ru}_{6} \mathrm{C}(\mathrm{CO})_{15}(\mathrm{NO})\right](\mathbf{2})$ were isolated from a reaction mixture obtained by bubbling $\mathrm{NO}$ gas through a $\mathrm{CH}_{2} \mathrm{Cl}_{2}$ solution of complex 1 at room temperature. On further bubbling of $\mathrm{NO}$ gas, $[\mathrm{PPN}]\left[\mathrm{Ru}_{6} \mathrm{C}(\mathrm{CO})_{12}(\mathrm{NO})_{3}\right](3)$ and $\mathrm{Ru}_{5} \mathrm{C}$ $(\mathrm{CO})_{14}(\mathrm{NO})\left(\mathrm{NO}_{2}\right)(4)$ were formed. These model reactions show that NO gas can easily substitute a carbonyl ligand of the original hexanuclear Ru cluster even at room temperature, but further addition of NO leads to stepwise cleavage of the metal-metal bond. ${ }^{11}$ Above $423 \mathrm{~K}$ in NO, decomposition of cluster 1 into an ill-defined insoluble precipitate has been noted.

In this paper, the structure of supported $\left[\mathrm{Ru}_{6} \mathrm{C}(\mathrm{CO})_{16}\right]^{2-}$ clusters is reported to establish the in situ structural benchmark of the application to catalytic reduction of NO. Appropriate inorganic oxide support material was investigated to finely control the surface $\mathrm{Ru}$ site structure to be most active for the catalytic removal of NO. To control the Ru site structure and accordingly the catalytic reactivity, major control factors were the basicity/acidity of the support, the extent of saturation of the surface metal site, and the specific surface area of the catalyst.

\section{Experimental Section}

Catalysts Preparation. The cluster 1 crystal was prepared by the method described in ref $16 . \mathrm{MgO}$ (specific surface area $200 \mathrm{~m}^{2} \mathrm{~g}^{-1}$ ) was prepared from $\mathrm{Mg}(\mathrm{OH})_{2}$ (Wako, 99.99\%) by heating at $773 \mathrm{~K}$ for $2 \mathrm{~h}$ in a vacuum. $\mathrm{Al}_{2} \mathrm{O}_{3}$ (Aerosil $\mathrm{C}$ ) $(100$ $\mathrm{m}^{2} \mathrm{~g}^{-1}$ ), anatase (major phase, $>83 \%$ ) $\mathrm{TiO}_{2}$ (Aerosil P25) $(50$ $\mathrm{m}^{2} \mathrm{~g}^{-1}$ ), rutile (the purity of $\mathrm{TiO}_{2}>99.8 \%$ ) $\mathrm{TiO}_{2}$ (JRC-TIO-3, given by the Catalysis Society of Japan) $\left(51 \mathrm{~m}^{2} \mathrm{~g}^{-1}\right)$, mesoporous $\mathrm{TiO}_{2}\left(1131 \mathrm{~m}^{2} \mathrm{~g}^{-1}\right.$, given by $\mathrm{H}$. Yoshitake at Yokohama National University), and $\mathrm{SiO}_{2}$ (Fuji-Silysia C-9709008) (273 $\mathrm{m}^{2} \mathrm{~g}^{-1}$ ) were heated at $673 \mathrm{~K}$ for $2 \mathrm{~h}$ in a vacuum except for the case of mesoporous $\mathrm{TiO}_{2}$ at $473 \mathrm{~K}$ to avoid sintering. Three kinds of $\mathrm{TiO}_{2}$ are denoted as $\mathrm{A}-\mathrm{TiO}_{2}, \mathrm{R}-\mathrm{TiO}_{2}$, and $\mathrm{M}-\mathrm{TiO}_{2}$, respectively. The crystal phase component ratio of $\mathrm{A}-\mathrm{TiO}_{2}$ and $\mathrm{R}-\mathrm{TiO}_{2}$ showed negligible change upon reaction with cluster 1 in a vacuum and in $\mathrm{NO}$ and/or CO gas at $423 \mathrm{~K}$, on the basis of the X-ray diffraction (XRD) observations. In the case of $\mathrm{M}-\mathrm{TiO}_{2}$, the XRD data remained unchanged; i.e., it was always in the amorphous state in these reaction conditions. Cluster 1 was reacted with $\mathrm{MgO}, \mathrm{Al}_{2} \mathrm{O}_{3}, \mathrm{~A}-\mathrm{TiO}_{2}, \mathrm{R}-\mathrm{TiO}_{2}, \mathrm{M}-\mathrm{TiO}_{2}$, and $\mathrm{SiO}_{2}$ at $290 \mathrm{~K}$ for $2 \mathrm{~h}$ in purified tetrahydrofuran (Wako, Special Grade, no stabilizer), and THF was subsequently removed in a vacuum. The loading of $\mathrm{Ru}$ was $1.5 \mathrm{wt} \%$ for all the samples. The supported carbido $\mathrm{Ru}$ clusters are denoted as $\left[\mathrm{Ru}_{6} \mathrm{C}\right] /$ support.

Noncarbido $[\mathrm{PPN}]_{2}\left[\mathrm{Ru}_{6}(\mathrm{CO})_{18}\right](\mathbf{5})$ cluster crystal was prepared by the method described in ref 17 . Cluster 5 was supported on $\mathrm{A}-\mathrm{TiO}_{2}$ in THF solution in a manner similar to the case of cluster 1 . This supported $\mathrm{Ru}$ cluster is denoted as $\left[\mathrm{Ru}_{6}\right] / \mathrm{A}-\mathrm{TiO}_{2}$. The Ru loading was 1.5 wt $\%$.

All the process of cluster catalysts preparation and transfer to reactor or sample cell was carried out in an argon (99.99\%) or helium (99.99\%) atmosphere. The incipient supported clusters were heated in $2.0 \mathrm{kPa}$ of $\mathrm{NO}$ for $30 \mathrm{~min}$ at $423-623 \mathrm{~K}$. Alternatively, the supported cluster was heated in NO $(2.0 \mathrm{kPa})$ $+\mathrm{CO}(2.0 \mathrm{kPa})+\mathrm{O}_{2}(0.56 \mathrm{kPa})$ or in $\mathrm{NO}+\mathrm{CO}+\mathrm{H}_{2} \mathrm{O}(3.1$ $\mathrm{kPa})$ for $3 \mathrm{~h}$ at $423 \mathrm{~K}$.

Conventional $\mathrm{Ru}$ catalyst was prepared by the impregnation of $\mathrm{A}-\mathrm{TiO}_{2}$ from an aqueous solution of $\mathrm{Ru}(\mathrm{NO})\left(\mathrm{NO}_{3}\right)_{3}(\mathrm{Ru} 1.5$ wt \%). Obtained powder was calcined in air at $623 \mathrm{~K}$ for $2 \mathrm{~h}$ and heated in $20 \mathrm{kPa}$ of $\mathrm{H}_{2}$ at $623 \mathrm{~K}$ for $2 \mathrm{~h}$ (denoted as $\mathrm{Ru} /$ $\left.\mathrm{A}-\mathrm{TiO}_{2}\right)$.
TABLE 1: Catalytic $\mathrm{N}_{2}$ Formation Rate at $423 \mathrm{~K}$ from NO $(2.0 \mathrm{kPa})$ and $\mathrm{CO}(2.0 \mathrm{kPa})$ on $\left[\mathrm{Ru}_{6} \mathrm{C}\right] / \mathrm{Oxides},\left[\mathrm{Ru}_{6}\right] / \mathrm{A}-\mathrm{TiO}_{2}$, and Conventional $\mathrm{Ru} / \mathrm{A}-\mathrm{TiO}_{2}$ Catalyst

\begin{tabular}{|c|c|c|c|c|}
\hline entry & catalyst & $\begin{array}{l}T_{\text {preheat }}{ }^{a} \\
(\mathrm{~K})\end{array}$ & $\begin{array}{l}\text { reaction } \\
\operatorname{gas}^{b}\end{array}$ & $\begin{array}{l}\mathrm{N}_{2} \text { formation rate } \\
\left(10^{-7} \mathrm{~mol} \text { of }\right. \\
\mathrm{N}_{2} \mathrm{~min}^{-1} \\
\mathrm{~g} \text { of cat. }\end{array}$ \\
\hline $\mathrm{a}$ & {$\left[\mathrm{Ru}_{6} \mathrm{C}\right] / \mathrm{A}-\mathrm{TiO}_{2}$} & 423 & $\mathrm{NO}+\mathrm{CO}$ & 5.1 \\
\hline $\mathrm{b}$ & & 523 & & 2.9 \\
\hline $\mathrm{c}$ & & 623 & & 2.5 \\
\hline d & & 423 & $\begin{array}{c}\mathrm{NO}+\mathrm{CO}+\mathrm{H}_{2} \mathrm{O} \\
(1.7 \mathrm{kPa})\end{array}$ & 10.9 \\
\hline $\mathrm{e}$ & & 423 & $\begin{array}{l}\mathrm{NO}+\mathrm{CO}+\mathrm{O}_{2} \\
(0.56 \mathrm{kPa})\end{array}$ & 2.6 \\
\hline $\mathrm{f}$ & {$\left[\mathrm{Ru}_{6}\right] / \mathrm{A}-\mathrm{TiO}_{2}$} & 423 & $\mathrm{NO}+\mathrm{CO}$ & 3.3 \\
\hline $\mathrm{g}$ & conv $\mathrm{Ru} / \mathrm{A}-\mathrm{TiO}_{2}$ & 423 & $\mathrm{NO}+\mathrm{CO}$ & 0.41 \\
\hline $\mathrm{h}$ & {$\left[\mathrm{Ru}_{6} \mathrm{C}\right] / \mathrm{Al}_{2} \mathrm{O}_{3}$} & 423 & & 1.6 \\
\hline i & {$\left[\mathrm{Ru}_{6} \mathrm{C}\right] / \mathrm{MgO}$} & 423 & & 1.5 \\
\hline $\mathrm{j}$ & {$\left[\mathrm{Ru}_{6} \mathrm{C}\right] / \mathrm{SiO}_{2}$} & 423 & & 0.83 \\
\hline
\end{tabular}

${ }^{a}$ Catalysts were heated in NO $(2.0 \mathrm{kPa})$ before the catalytic test. ${ }^{b}$ The pressure of NO $(2.0 \mathrm{kPa})$ and $\mathrm{CO}(2.0 \mathrm{kPa})$ was fixed.

XAFS Measurements. The Ru K-edge XAFS spectra were measured at 290 or $13 \mathrm{~K}$ using beamline $10 \mathrm{~B}$ of the Photon Factory in the National Laboratory for High Energy Physics. The accumulation ring energy was $2.5 \mathrm{GeV}$, and the ring current was 400-290 mA. The bending-magnet beamline 10B utilized a channel-cut double crystal monochromator of Si(311). Samples were placed vertically. The incident and transmitted X-rays were monitored by ion chambers filled with Ar for $I_{0}$ and $\mathrm{Kr}$ for $I$. In situ prepared samples were transferred to a Pyrex glass cell, and transported to the beamline at Tsukuba.

EXAFS Analysis. The EXAFS spectra were analyzed by the program EXAFSH. ${ }^{18}$ The postedge background subtraction was performed by calculating the three-block cubic spline, followed by the normalization by using the Victoreen equation. Normalization was performed at $k=4.0 \AA^{-1}$ relative to the derivative maximum of the absorption edge. The Fourier transform of $k^{3}$ weighted $\chi$ function was carried out over the range $k_{\min }=3.0$ and $k_{\max }=13.0-14.0 \AA^{-1}$ with the window function of 0.5 $\AA^{-1}$ on both sides of the region. The inverse Fourier transform was performed in the filtering range $r=1.0-4.5 \AA$.

The curve fitting analysis was performed in the range $k_{\min }=$ 4 and $k_{\max }=12.0-13.0 \AA^{-1}$ by the empirical phase shift and amplitude functions extracted from the EXAFS of model compounds: $\mathrm{Ru}$ powder for $\mathrm{Ru}-\mathrm{Ru}$ bond (2.67 $\AA$ ), $\mathrm{RuO}_{2}$ powder for $\mathrm{Ru}-\mathrm{O}$ bond $(1.98 \AA), \mathrm{Ru}_{3}(\mathrm{CO})_{12}$ crystal for $\mathrm{Ru}-\mathrm{C}$ bond $(1.93 \AA),\left[\mathrm{RuCl}_{2}(\mathrm{CO})_{3}\right]_{2}$ crystal for $\mathrm{Ru}(-\mathrm{C}-) \mathrm{O}$ bond $(3.03$ $\AA$ ), and $[\mathrm{PPN}]_{2}\left[\mathrm{Ru}_{6} \mathrm{C}(\mathrm{CO})_{16}\right]$ crystal for $\mathrm{Ru}(-\mathrm{C}-) \mathrm{Ru}$ bond (4.09 $\AA) .{ }^{5}$ The fit quality was evaluated by calculating the $R$ factor $\left(R_{f}\right)$.

$$
R_{f}=\int\left|k^{3} \chi^{\mathrm{obs}}(k)-k^{3} \chi^{\mathrm{calc}}(k)\right|^{2} \mathrm{~d} k / \int\left|k^{3} \chi^{\mathrm{obs}}(k)\right|^{2} \mathrm{~d} k
$$

\section{Results}

Effects of Support. The catalytic reactivity of $\left[\mathrm{Ru}_{6} \mathrm{C}\right] / \mathrm{A}$ $\mathrm{TiO}_{2}$ for the NO reduction was preliminarily examined in the heating temperature range 423-623 K (Table 1a-c). Sample $\left[\mathrm{Ru}_{6} \mathrm{C}\right] / \mathrm{A}-\mathrm{TiO}_{2}$ previously heated in $\mathrm{NO}$ at $423 \mathrm{~K}$ showed highest activity of $\mathrm{N}_{2}$ formation as high as $5.1 \times 10^{-7} \mathrm{~mol}$ of $\mathrm{N}_{2} \min ^{-1} \mathrm{~g}_{\text {cat }}{ }^{-1}$ in the $\mathrm{NO}+\mathrm{CO}$ reaction. In the following structural study, we focused on the $\mathrm{TiO}_{2}$ case because the catalytic test results were best in the case rather than the cases using other supports (Table 1).

The EXAFS spectrum for $\left[\mathrm{Ru}_{6} \mathrm{C}\right] / \mathrm{A}-\mathrm{TiO}_{2}$ heated in $\mathrm{NO}(2.0$ $\mathrm{kPa}$ ) at $423 \mathrm{~K}$ is shown in Figure 1. The best-fit result of the 

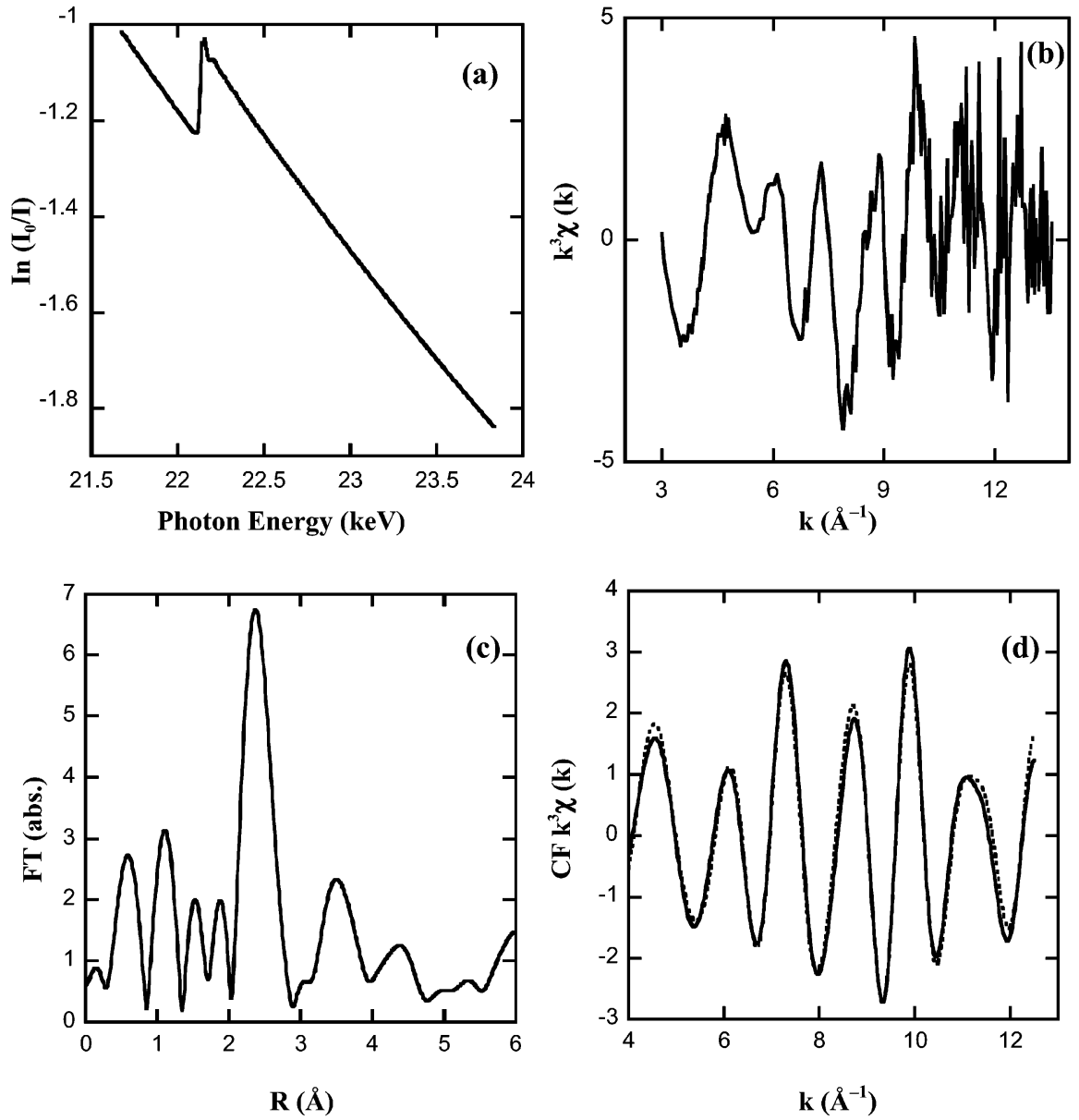

Figure 1. Ru K-edge EXAFS for $\left[\mathrm{Ru}_{6} \mathrm{C}\right] / \mathrm{A}-\mathrm{TiO}_{2}$ in $\mathrm{NO}(2.0 \mathrm{kPa})$ at $423 \mathrm{~K}$ : (a) raw spectrum; (b) the $k^{3}$-weighted EXAFS oscillation; (c) its associated Fourier transform; (d) the curve fit analysis. Key: $(-)$ observed; $(\cdots)$ calculated.

TABLE 2: Structural Parameters Based on the Curve Fit Analysis for the Ru K-Edge EXAFS for Supported Ru Cluster Catalysts and Reference Metric Data of Cluster Crystals

\begin{tabular}{|c|c|c|c|c|c|c|c|c|c|c|c|c|c|c|c|c|c|c|c|}
\hline \multirow[b]{2}{*}{ entry } & \multirow[b]{2}{*}{ catalysts } & \multirow{2}{*}{$\begin{array}{l}T_{\text {Preheat }}^{b} \\
(\mathrm{~K})\end{array}$} & \multirow{2}{*}{$\begin{array}{l}\text { reaction } \\
\text { gas }^{c}\end{array}$} & \multicolumn{3}{|c|}{$\mathrm{Ru}-\mathrm{O}$} & \multicolumn{3}{|c|}{$\begin{array}{c}\mathrm{Ru}-\mathrm{C} \text { or } \\
\mathrm{Ru}-\mathrm{N}\end{array}$} & \multicolumn{3}{|c|}{$\mathrm{Ru}-\mathrm{Ru}$} & \multicolumn{3}{|c|}{$\begin{array}{c}\mathrm{Ru}(-\mathrm{C}-) \mathrm{O} \text { or } \\
\mathrm{Ru}(-\mathrm{N}-) \mathrm{O}\end{array}$} & \multicolumn{3}{|c|}{$\mathrm{Ru}(-\mathrm{C}-) \mathrm{Ru}$} & \multirow{2}{*}{$\begin{array}{l}R_{\mathrm{f}} \\
(\%)\end{array}$} \\
\hline & & & & $N$ & $r(\AA)$ & $\Delta\left(\sigma^{2}\right)^{a}$ & $N$ & $r(\AA)$ & $\Delta\left(\sigma^{2}\right)^{a}$ & $N$ & $r(\AA)$ & $\Delta\left(\sigma^{2}\right)^{a}$ & $N$ & $r(\AA)$ & $\Delta\left(\sigma^{2}\right)^{a}$ & $N$ & $r(\AA)$ & $\Delta\left(\sigma^{2}\right)^{a}$ & \\
\hline $\mathrm{a}$ & {$\left[\mathrm{Ru}_{6} \mathrm{C}\right] / \mathrm{A}-\mathrm{TiO}_{2}$} & 423 & & & & & 3.0 & 1.91 & 9.0 & 3.5 & 2.87 & 2.1 & 3.0 & 3.05 & 1.4 & 0.7 & 3.99 & 2.3 & 1.7 \\
\hline $\mathrm{b}$ & & & $\mathrm{NO}-\mathrm{CO}$ & & & & 1.5 & 2.11 & -0.2 & 3.5 & 2.87 & 4.2 & 2.1 & 3.08 & 3.2 & 0.6 & 4.05 & -0.2 & 2.6 \\
\hline $\mathrm{c}$ & & & $\begin{array}{c}\mathrm{NO}-\mathrm{CO}-\mathrm{H}_{2} \mathrm{O} \\
(3.1 \mathrm{kPa})\end{array}$ & & & & 2.0 & 2.12 & 2.8 & 3.5 & 2.87 & 5.6 & 2.3 & 3.08 & 7.3 & 0.6 & 4.07 & 1.4 & 3.8 \\
\hline d & & & $\begin{array}{r}\mathrm{NO}-\mathrm{CO}-\mathrm{O}_{2} \\
(0.56 \mathrm{kPa})\end{array}$ & 1.7 & 2.05 & 5.9 & 0.6 & 1.83 & -2.9 & & & & 0.6 & 2.94 & 0.11 & & & & 4.0 \\
\hline $\mathrm{e}$ & & 523 & & 1.9 & 2.00 & -2.6 & & & & & & & & & & & & & 2.0 \\
\hline $\mathrm{f}$ & & 623 & & 1.7 & 2.08 & -0.3 & 0.8 & 2.02 & -1.7 & 2.4 & 2.66 & 4.9 & 1.0 & 2.87 & 2.4 & & & & 0.0 \\
\hline $\mathrm{g}$ & {$\left[\mathrm{Ru}_{6} \mathrm{C}\right] / \mathrm{R}-\mathrm{TiO}_{2}$} & 423 & & & & & 3.0 & 1.91 & 7.4 & 3.6 & 2.86 & 4.9 & 3.0 & 3.04 & 1.5 & 0.7 & 4.10 & 0.6 & 3.8 \\
\hline $\mathrm{h}$ & {$\left[\mathrm{Ru}_{6} \mathrm{C}\right] / \mathrm{M}-\mathrm{TiO}_{2}$} & & & 1.8 & 2.10 & 2.9 & 1.0 & 1.97 & 5.5 & 1.4 & 2.65 & 9.9 & 1.4 & 2.95 & 5.0 & & & & 0.2 \\
\hline $\mathrm{i}$ & {$\left[\mathrm{Ru}_{6} \mathrm{C}\right] / \mathrm{SiO}_{2}$} & & & & & & 2.5 & 1.87 & 1.3 & 4.1 & 2.82 & 2.7 & 2.5 & 2.98 & 0.5 & 0.8 & 4.12 & 0.0 & 3.5 \\
\hline $\mathrm{j}$ & & & $\mathrm{NO}-\mathrm{CO}$ & 1.3 & 2.06 & -1.7 & 0.9 & 2.01 & -1.7 & 4.0 & 2.65 & 8.7 & 0.9 & 2.89 & -0.7 & 0.3 & 4.05 & -1.7 & 0.9 \\
\hline $\mathrm{k}$ & {$\left[\mathrm{Ru}_{6} \mathrm{C}\right] / \mathrm{Al}_{2} \mathrm{O}_{3}$} & & & 1.3 & 2.03 & -3.1 & 1.0 & 1.97 & -0.9 & 0.8 & 2.63 & 4.6 & 1.2 & 2.88 & 2.5 & & & & 3.4 \\
\hline 1 & {$\left[\mathrm{Ru}_{6} \mathrm{C}\right] / \mathrm{MgO}$} & & & 2.2 & 2.04 & 0.1 & 1.0 & 1.97 & 1.1 & 2.7 & 2.65 & 9.1 & 1.0 & 2.87 & 2.6 & & & & 2.3 \\
\hline $\mathrm{m}$ & {$\left[\mathrm{Ru}_{6}\right] / \mathrm{A}-\mathrm{TiO}_{2}$} & & & 1.9 & 2.05 & 1.6 & 0.8 & 1.76 & 8.7 & & & & 0.8 & 2.90 & 2.0 & & & & 1.5 \\
\hline $\mathrm{n}$ & & & $\mathrm{NO}-\mathrm{CO}$ & 1.9 & 2.05 & 5.7 & 0.6 & 1.83 & 3.3 & & & & 0.6 & 2.93 & 1.5 & & & & 3.2 \\
\hline o & $\mathrm{Ru} / \mathrm{A}-\mathrm{TiO}_{2}$ & & & & & & & & & 11.1 & 2.68 & 1.2 & & & & & & & 0.8 \\
\hline $\mathrm{p}$ & {$\left[\mathrm{Ru}_{6} \mathrm{C}(\mathrm{CO})_{16}\right]^{2-d}$} & - & & & & & 3.3 & 1.95 & & 4.0 & 2.89 & & 3.3 & 3.03 & & 1.0 & 4.09 & & \\
\hline$q$ & {$\left[\mathrm{Ru}_{6} \mathrm{C}(\mathrm{CO})_{12}(\mathrm{NO})_{3}\right]^{-d}$} & - & & & & & 3 & 1.93 & & 4 & 2.89 & & 3 & 3.03 & & 1 & 4.09 & & \\
\hline
\end{tabular}

${ }^{a}$ The unit of $\Delta\left(\sigma^{2}\right)$ is $10^{-3} \AA^{2} .{ }^{b}$ In NO $(2.0 \mathrm{kPa})$ for $30 \mathrm{~min} .{ }^{c} \mathrm{NO}(2.0 \mathrm{kPa})$ and CO $(2.0 \mathrm{kPa})$. Temperature $=423 \mathrm{~K} .{ }^{d}$ Determined by X-ray crystallographic analysis. The contribution of NO ligand was considered for cluster 3.

curve-fitting analysis for the spectrum is listed in Table 2a. In its associated Fourier transform (Figure 1c), the peaks at 1.32.0, 2.3, and $3.5 \AA$ (phase shift uncorrected) were ascribed to $\mathrm{Ru}-\mathrm{C}, \mathrm{Ru}-\mathrm{Ru}+\mathrm{Ru}(-\mathrm{C}-) \mathrm{O}$, and $\mathrm{Ru}(-\mathrm{C}-) \mathrm{Ru}$ bonds, respectively. The first and second peaks also include the contribution of $\mathrm{Ru}-\mathrm{N}$ and $\mathrm{Ru}(-\mathrm{N}-) \mathrm{O}$, respectively, because the average bond length of $\mathrm{Ru}-\mathrm{N}(1.76 \AA)$ is similar to that of $\mathrm{Ru}-\mathrm{C}(1.97 \AA)$ and the average bond length of $\mathrm{Ru}(-\mathrm{N}-) \mathrm{O}$ $(3.00 \AA)$ is similar to that of $\mathrm{Ru}(-\mathrm{C}-) \mathrm{O}(3.03 \AA)$ for cluster 3. ${ }^{19}$ The obtained bond lengths $(r)$ and coordination numbers $(N)$ of $\mathrm{Ru}-\mathrm{C}(1.91 \AA$ with $N=3.0), \mathrm{Ru}-\mathrm{Ru}(2.87 \AA$ with $N$ $=3.5), \mathrm{Ru}(-\mathrm{C}-) \mathrm{O}(3.05 \AA$ with $N=3.0)$, and $\mathrm{Ru}(-\mathrm{C}-) \mathrm{Ru}$ 

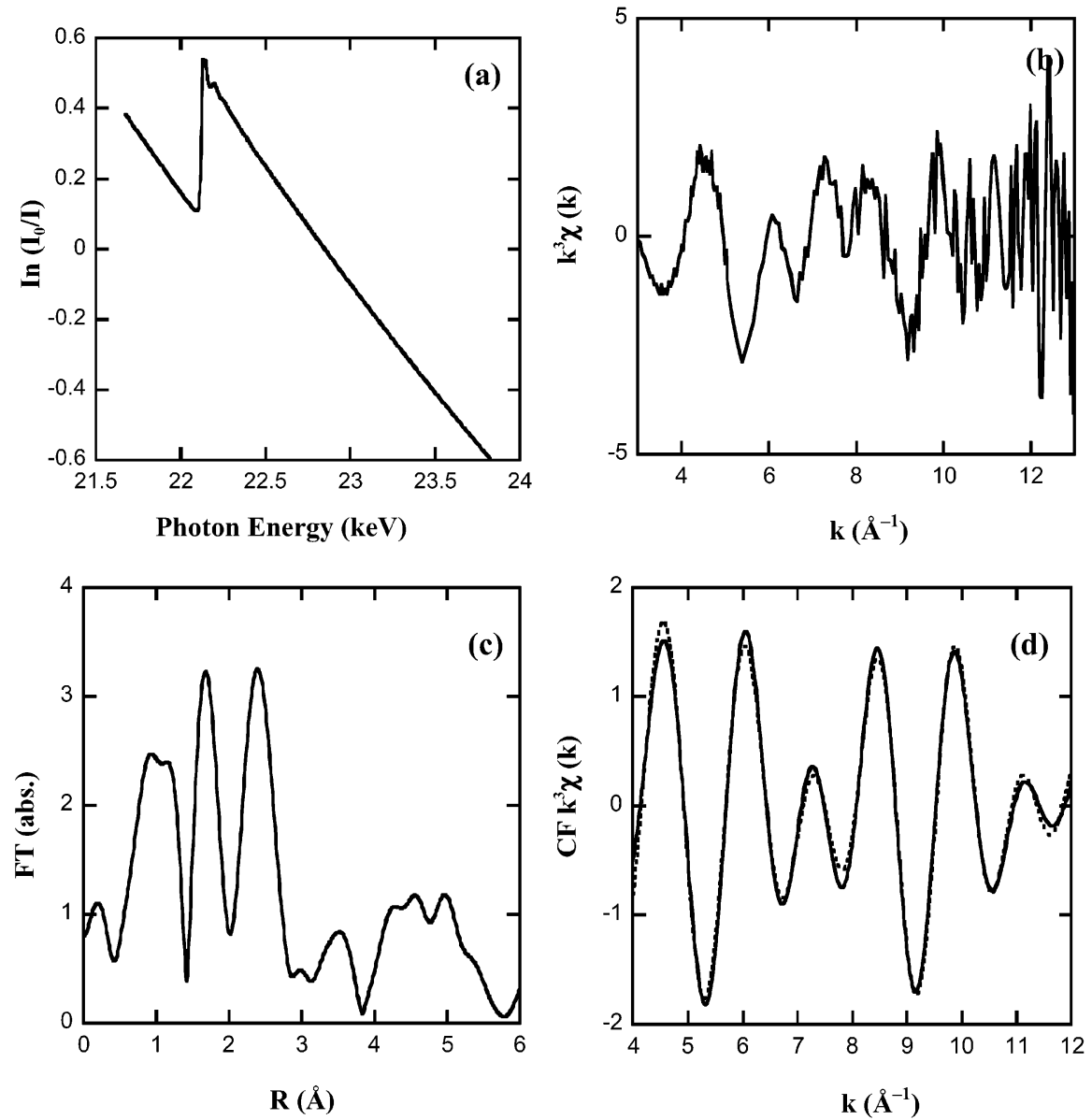

Figure 2. $\mathrm{Ru} \mathrm{K}$-edge EXAFS for $\left[\mathrm{Ru}_{6} \mathrm{C}\right] / \mathrm{M}-\mathrm{TiO}_{2}$ in $\mathrm{NO}(2.0 \mathrm{kPa})$ at $423 \mathrm{~K}$ : (a) raw spectrum; (b) the $k^{3}$-weighted EXAFS oscillation; (c) its associated Fourier transform; (d) the curve fit analysis. Key: (-) observed; ( $\cdots)$ calculated.

(3.99 $\AA$ with $N=0.7$ ) (Table 2a) were essentially identical to the corresponding values based on XRD crystallographic data of cluster 3 (Table 2q), ${ }^{1-13}$ taking the maximum error of coordination number by EXAFS $(\approx 30 \%)$ into account. It is known that the intensity of the $\mathrm{Ru}(-\mathrm{C}-) \mathrm{Ru}$ multiple scattering peak is greatly reduced when the $\mathrm{Ru}_{6} \mathrm{C}$ framework distorts from octahedral to lower symmetry. According to the symmetry change, the $\theta_{\mathrm{Ru}-\mathrm{C}-\mathrm{Ru}}$ angle decreases from $\pi .^{20}$ This may be the reason that the $N$ for the $\mathrm{Ru}-\mathrm{C}-\mathrm{Ru}$ bond (0.7) was smaller by $30 \%$ than the case of cluster $\mathbf{3}$ crystal.

The EXAFS analysis results of $\left[\mathrm{Ru}_{6} \mathrm{C}\right] / \mathrm{R}-\mathrm{TiO}_{2}$ heated in NO $(2.0 \mathrm{kPa})$ at $423 \mathrm{~K}$ were essentially identical to the above case of $\left[\mathrm{Ru}_{6} \mathrm{C}\right] / \mathrm{A}-\mathrm{TiO}_{2}($ Table $2 \mathrm{a}, \mathrm{g})$. The numbers of $\mathrm{CO}$ and $\mathrm{NO}$ ligands that remained in the EXAFS sample of $\left[\mathrm{Ru}_{6} \mathrm{C}\right] / \mathrm{A}-\mathrm{TiO}_{2}$ were evaluated by the gas chromatograph (GC). They were 12.1 and 1.9, respectively, per one $\mathrm{Ru}_{6} \mathrm{C}$ cluster unit. The number of NO is 3 in the crystal of cluster $\mathbf{3}$. The GC data suggest that cluster 1 was transformed to cluster $\mathbf{3}$ by the reaction of $\mathrm{NO}$ at $423 \mathrm{~K}$, supported on the $\mathrm{TiO}_{2}$ surface. The $\mathrm{Ru}$ site to accommodate one more NO molecule may be used instead to form bond(s) with surface oxygen atom(s) of $\mathrm{TiO}_{2}$.

The EXAFS spectrum for $\left[\mathrm{Ru}_{6} \mathrm{C}\right] / \mathrm{M}-\mathrm{TiO}_{2}$ heated in NO $(2.0$ $\mathrm{kPa})$ at $423 \mathrm{~K}$ is shown in Figure 2 . The peak at $3.5 \AA$ in the Fourier transform (c) was not fit well with the empirical parameters of the $\mathrm{Ru}(-\mathrm{C}-) \mathrm{Ru}$ bond (Table $2 \mathrm{~h}$ ). The $\mathrm{Ru}-\mathrm{Ru}$ bond distance decreased from 2.89 for cluster 1 crystal to 2.65 $\AA$. This value is a typical bond distance for the hcp metallic Ru crystal. On the basis of the bond distance of $\mathrm{Ru}-\mathrm{Ru}$ first coordination, the peak at $3.5 \AA$ may be due to the next-nearest Ru site. ${ }^{21}$ The obtained $N$ value for $\mathrm{Ru}-\mathrm{Ru}$ first coordination was 1.4. The $\mathrm{Ru}$ hexanuclear structure framework should have split into smaller fragments in this case.

In the cases of $\left[\mathrm{Ru}_{6} \mathrm{C}\right] / \mathrm{Al}_{2} \mathrm{O}_{3}$ and $\left[\mathrm{Ru}_{6} \mathrm{C}\right] / \mathrm{MgO}$, no peak appeared in the region of $\mathrm{Ru}(-\mathrm{C}-) \mathrm{Ru}$ bond in the $k^{3}$-weighted Fourier transform of EXAFS $\chi$ function (not shown). Best fit values are listed in Table $2 \mathrm{k}, 1$. On the basis of the $r_{\mathrm{Ru}-\mathrm{Ru}}$ values (2.63-2.65 $\AA$ ) and the $N$ values $(0.8-2.7)$, the smaller $\mathrm{Ru}$ cluster split from the six-atom ensemble and/or atomically dispersed $\mathrm{Ru}$ cations should be distributed on the $\mathrm{Al}_{2} \mathrm{O}_{3}$ and $\mathrm{MgO}$ surface at $423 \mathrm{~K}$ in $\mathrm{NO}$.

In the case of $\left[\mathrm{Ru}_{6} \mathrm{C}\right] / \mathrm{SiO}_{2}$ (Table $2 \mathrm{i}$ ), best-fit result was similar to the case of $\left[\mathrm{Ru}_{6} \mathrm{C}\right] / \mathrm{A}-\mathrm{TiO}_{2}$ and $\left[\mathrm{Ru}_{6} \mathrm{C}\right] / \mathrm{R}-\mathrm{TiO}_{2}$ and accordingly to that of the cluster $\mathbf{3}$ crystal. The $\mathrm{GC}$ evaluation of the $\mathrm{CO}$ ligand number for the EXAFS sample of $\left[\mathrm{Ru}_{6} \mathrm{C}\right] /$ $\mathrm{SiO}_{2}$ was 13.9 per a $\mathrm{Ru}_{6} \mathrm{C}$ cluster unit. No $\mathrm{NO}$ gas derived from the sample was detected $\left(<6 \times 10^{-9} \mathrm{~mol}\right)$. The $\left[\mathrm{Ru}_{6} \mathrm{C}\right]$ cluster supported on $\mathrm{SiO}_{2}$ retained the $\mathrm{Ru}_{6}$ framework in $\mathrm{NO}$ at 423 $\mathrm{K}$, probably due to the lower reactivity between the cluster and the $\mathrm{SiO}_{2}$ surface. Essentially intact cluster 1 may remain on the $\mathrm{SiO}_{2}$ surface. (Structurally) unperturbed cluster 1 is less reactive with NO gas rather than partially decarbonylated cluster. ${ }^{3-6}$

In summary, the transformation of cluster $\mathbf{1}$ to $\mathbf{3}$ was suggested on $\mathrm{A}-\mathrm{TiO}_{2}$ and $\mathrm{R}-\mathrm{TiO}_{2}$ in $\mathrm{NO}$ at $423 \mathrm{~K}$. The cleavage of $\mathrm{Ru}-\mathrm{Ru}$ bond in the $\mathrm{Ru}_{6} \mathrm{C}$ cluster was typically observed for $\left[\mathrm{Ru}_{6} \mathrm{C}\right] / \mathrm{M}-\mathrm{TiO}_{2},\left[\mathrm{Ru}_{6} \mathrm{C}\right] / \mathrm{Al}_{2} \mathrm{O}_{3}$, and $\left[\mathrm{Ru}_{6} \mathrm{C}\right] / \mathrm{MgO}$. The retained $\mathrm{Ru}_{6} \mathrm{C}$ framework in the case of $\left[\mathrm{Ru}_{6} \mathrm{C}\right] / \mathrm{SiO}_{2}$ was suggested to be nonreactive with the NO gas.

Effects of Heating Temperature in NO. The Fourier transforms of EXAFS spectra for $\left[\mathrm{Ru}_{6} \mathrm{C}\right] / \mathrm{A}-\mathrm{TiO}_{2}$ in $\mathrm{NO}(2.0$ $\mathrm{kPa})$ at $423-623 \mathrm{~K}$ are illustrated in Figure 3. The results of 


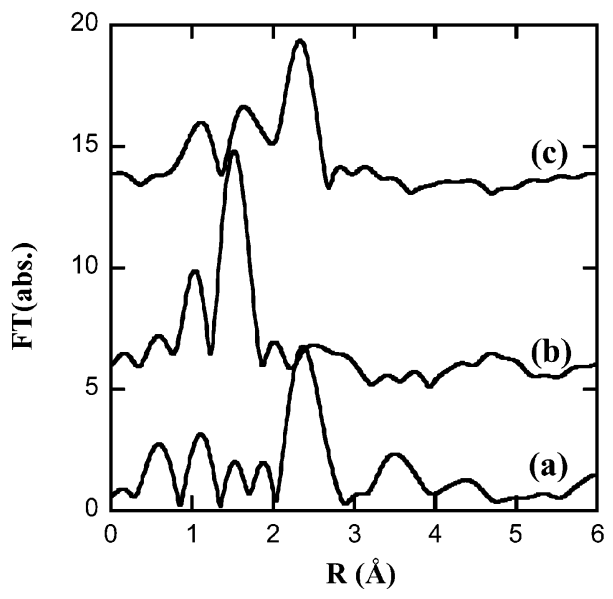

Figure 3. Fourier transforms of $k^{3}$-weighted Ru K-edge EXAFS $\chi$ function for $\left[\mathrm{Ru}_{6} \mathrm{C}\right] / \mathrm{A}-\mathrm{TiO}_{2}$ in $\mathrm{NO}(2.0 \mathrm{kPa})$ at $423(\mathrm{a}), 523(\mathrm{~b})$, and $623 \mathrm{~K}(\mathrm{c})$.

the curve-fitting analysis are listed in Table 2a,e,f. The result at $423 \mathrm{~K}$ was already described in the previous section. The peak originating from $\mathrm{Ru}(-\mathrm{C}-) \mathrm{Ru}$ and $\mathrm{Ru}-\mathrm{Ru}$ bonds disappeared at $523 \mathrm{~K}$ (Figure $3 \mathrm{~b}$ ). All the $\mathrm{Ru}-\mathrm{Ru}$ bonds in the $\mathrm{Ru}_{6} \mathrm{C}$ framework were cleaved and hence the $\mathrm{Ru}$ cation was atomically dispersed, stabilized by the bonding with approximately two (in average) surface oxygen atoms at the distance of $2.00 \AA$. With heating in $\mathrm{NO}$ at $623 \mathrm{~K}$, a peak due to $\mathrm{Ru}-\mathrm{Ru}$ bonds appeared again at $2.4 \AA$ in Figure $3 \mathrm{c}$ (phase shift uncorrected). The $\mathrm{Ru}-\mathrm{Ru}$ first coordination average distance was determined to be $2.66 \AA$. The diagonal $\mathrm{Ru}(-\mathrm{C}-) \mathrm{Ru}$ coordination peak was not observed. As the $N_{\mathrm{Ru}-\mathrm{Ru}}$ value was as small as 2.4 , less than six $\mathrm{Ru}$ atoms reconstituted one $\mathrm{Ru}$ cluster (unit) in average. The carbido carbon should not remain inside the $\mathrm{Ru}$ cluster, and accordingly, the $\mathrm{Ru}$ microparticle smaller than $1.0 \mathrm{~nm}$ had the metallic nature rather than ruthenium metal carbide.

In summary, retained $\mathrm{Ru}_{6} \mathrm{C}$ framework at $423 \mathrm{~K}$ entirely split into single Ru cations at $523 \mathrm{~K}$. At $623 \mathrm{~K}$, the metallic Ru cluster was reorganized and the particle size should be very small (smaller than $1.0 \mathrm{~nm}$ ) because the $\mathrm{Ru}-\mathrm{Ru}$ coordination number was only 2.4 .

Effects of Carbido Carbon. The catalytic reactivity of NO decomposition for noncarbido $\left[\mathrm{Ru}_{6}\right] / \mathrm{A}-\mathrm{TiO}_{2}$ was compared to that of carbido $\left[\mathrm{Ru}_{6} \mathrm{C}\right] / \mathrm{A}-\mathrm{TiO}_{2}$ both heated in the presence of $\mathrm{NO}(2.0 \mathrm{kPa})$ at $423 \mathrm{~K}$. The catalytic $\mathrm{N}_{2}$ formation rate starting from $\mathrm{NO}+\mathrm{CO}$ gas at $423 \mathrm{~K}$ on $\left[\mathrm{Ru}_{6}\right] / \mathrm{A}-\mathrm{TiO}_{2}$ was found to be only $65 \%$ of that on $\left[\mathrm{Ru}_{6} \mathrm{C}\right] / \mathrm{A}-\mathrm{TiO}_{2}$ (Table $\left.1 \mathrm{a}, \mathrm{f}\right)$. The EXAFS data for $\left[\mathrm{Ru}_{6}\right] / \mathrm{A}-\mathrm{TiO}_{2}$ treated in $\mathrm{NO}(2.0 \mathrm{kPa})$ at $423 \mathrm{~K}$ are depicted in Figure 4. In our control EXAFS measurement for unsupported cluster $\mathbf{5}$ crystal, the peak attributed to second nearest $\mathrm{Ru}-\mathrm{Ru}$ bond (diagonal line of octahedral, 3.96-4.09 $\AA$ ) was not observed in the Fourier transform of Ru K-edge EXAFS spectrum at $290 \mathrm{~K}$. Due to this reason, only the fit value of the first coordination $\mathrm{Ru}-\mathrm{Ru}$ peak was used to judge the retention of the $\mathrm{Ru}_{6}$ framework in the case of supported noncarbido cluster. The best fit consisted of $\mathrm{Ru}-\mathrm{O}, \mathrm{Ru}-\mathrm{C}$ (or $\mathrm{Ru}-\mathrm{N})$, and $\mathrm{Ru}(-\mathrm{C}-) \mathrm{O}$ (or $\mathrm{Ru}(-\mathrm{N}-) \mathrm{O}$ ) (Table $2 \mathrm{~m})$. The fit including the $\mathrm{Ru}-\mathrm{Ru}$ bond contribution was rather worse. A plausible $\mathrm{Ru}$ site structure was spontaneously atomically dispersed $\mathrm{Ru}$ cations and/or a very small $\mathrm{Ru}$ cluster (less than six $\mathrm{Ru}$ atoms ensemble) on the $\mathrm{TiO}_{2}$ surface, in contrast with
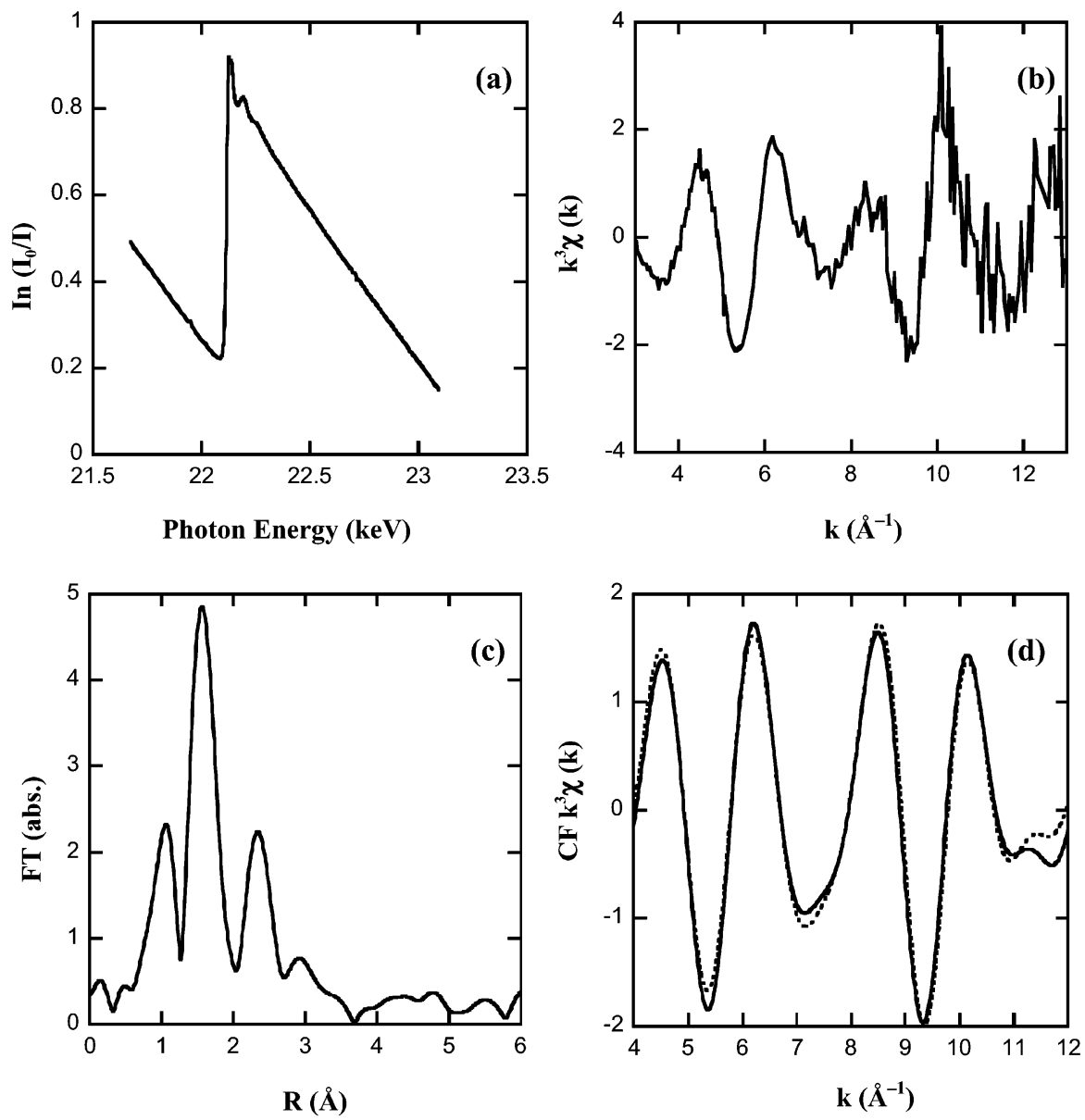

Figure 4. $\mathrm{Ru} \mathrm{K}$-edge EXAFS for $\left[\mathrm{Ru}_{6}\right] / \mathrm{A}-\mathrm{TiO}_{2}$ in $\mathrm{NO}(2.0 \mathrm{kPa})$ at $423 \mathrm{~K}$ : (a) raw spectrum; (b) the $k^{3}$-weighted EXAFS oscillation; (c) its associated Fourier transform; (d) the curve fit analysis. Key: ( - ) observed ( $\cdots$ ) calculated. 


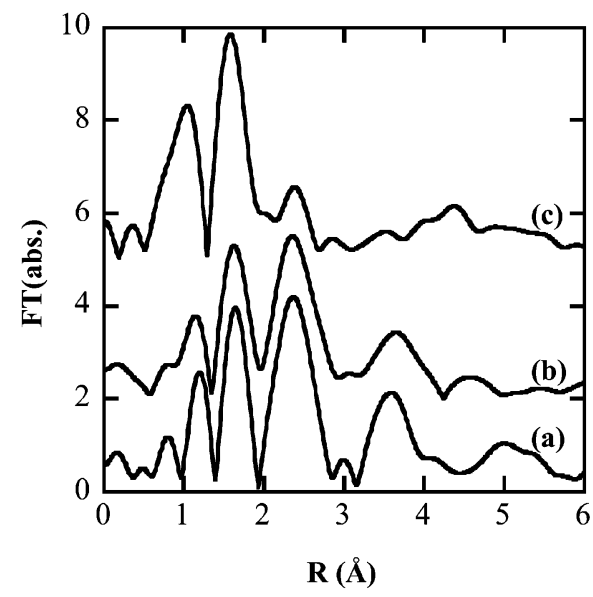

Figure 5. Fourier transforms of $k^{3}$-weighted Ru K-edge EXAFS $\chi$ function for $\left[\mathrm{Ru}_{6} \mathrm{C}\right] / \mathrm{A}-\mathrm{TiO}_{2}$ in $\mathrm{NO}(2.0 \mathrm{kPa})+\mathrm{CO}(2.0 \mathrm{kPa})(\mathrm{a}), \mathrm{NO}$ $+\mathrm{CO}+\mathrm{H}_{2} \mathrm{O}(3.1 \mathrm{kPa})(\mathrm{b})$, and $\mathrm{NO}+\mathrm{CO}+\mathrm{O}_{2}(0.56 \mathrm{kPa})(\mathrm{c})$, all at $423 \mathrm{~K}$.

the $\mathrm{Ru}_{6} \mathrm{C}$ framework being retained in the case of $\left[\mathrm{Ru}_{6} \mathrm{C}\right] / \mathrm{A}-$ $\mathrm{TiO}_{2}$ in $\mathrm{NO}(2.0 \mathrm{kPa})$ at $423 \mathrm{~K}$.

Ru Site Structure during Catalysis. The Ru cluster site structure of $\left[\mathrm{Ru}_{6} \mathrm{C}\right] / \mathrm{A}-\mathrm{TiO}_{2}$ was investigated during catalysis in the presence of $\mathrm{NO}(2.0 \mathrm{kPa})+\mathrm{CO}(2.0 \mathrm{kPa})$ at $423 \mathrm{~K}$. The reaction condition corresponds to the best removal rate of $\mathrm{NO}$ in the series of model catalysts (Table $2 b$ ). The catalysts under the in situ catalytic reaction condition were quenched and the XAFS spectrum was measured at $290 \mathrm{~K}$. The $N_{\mathrm{Ru}-\mathrm{Ru}}$ and $N_{\mathrm{Ru}(-\mathrm{C}-) \mathrm{Ru}}$ values were 3.5 and 0.6 , being effectively equivalent to the case of Ru cluster site in only $\mathrm{NO}$ at $423 \mathrm{~K}$ (3.5 and 0.7, respectively, Table 2a). The addition of gas-phase carbon monoxide did not have significant effects on the $\mathrm{Ru}$ cluster structure supported over $\mathrm{A}-\mathrm{TiO}_{2}$.

In contract, the $N_{\mathrm{Ru}(-\mathrm{C}-) \mathrm{Ru}}$ value in the case of $\left[\mathrm{Ru}_{6} \mathrm{C}\right] / \mathrm{SiO}_{2}$ in $\mathrm{NO}(2.0 \mathrm{kPa})+\mathrm{CO}(2.0 \mathrm{kPa})$ at $423 \mathrm{~K}$ decreased from 0.8 to 0.3 (Table $2 \mathrm{j}$ ), suggesting the deformation of $\mathrm{Ru}$ octahedral framework. The $\mathrm{Ru}_{6}$ unit should have contracted to microparticles of hcp metallic nature on the basis of the obtained $\mathrm{Ru}-\mathrm{Ru}$ distance of $2.65 \AA$. The reason of the difference of the $\mathrm{Ru}$ site structure is not clear whether in the presence of NO or in the presence of $\mathrm{NO}+\mathrm{CO}$ (Table $2 \mathrm{i}, \mathrm{j})$.

Effects of $\mathrm{O}_{2}$ and Water. The $\mathrm{N}_{2}$ formation rate at $423 \mathrm{~K}$ starting from NO $(2.0 \mathrm{kPa})+\mathrm{CO}(2.0 \mathrm{kPa})$ on $\left[\mathrm{Ru}_{6} \mathrm{C}\right] / \mathrm{A}-\mathrm{TiO}_{2}$ increased by $112 \%$ when $1.7 \mathrm{kPa}$ of water was mixed with the reaction gas (Table 1d). When $0.56 \mathrm{kPa}$ of $\mathrm{O}_{2}$ was mixed with the reaction gas, the $\mathrm{N}_{2}$ formation rate decreased by $49 \%$ (Table 1e).

Figure 5 compares the Fourier transforms of $k^{3}$-weighted EXAFS $\chi$ function in $\mathrm{NO}+\mathrm{CO}(\mathrm{a})$, in $\mathrm{NO}+\mathrm{CO}+\mathrm{H}_{2} \mathrm{O}(\mathrm{b})$, and in $\mathrm{NO}+\mathrm{CO}+\mathrm{O}_{2}$ (c). The results of curve fitting analysis are listed in Table 2a,c,d. Added water did not have a significant effect on the FT data (Figure 5a,b). Upon addition of $\mathrm{O}_{2}$ to the reaction mixture, the peak around $3.5 \AA$ disappeared and the peak at $2.4 \AA$ became very weak (Figure 5c). The transformed $\mathrm{Ru}$ site structure may be similar to that in NO at $523 \mathrm{~K}$ (Figure $3 \mathrm{~b}$, Table 2e) except that one $\mathrm{CO}$ or NO ligand remained to one/two $\mathrm{Ru}$ atom(s) when the $\mathrm{O}_{2}$ gas was introduced to $\left[\mathrm{Ru}_{6} \mathrm{C}\right] /$ $\mathrm{A}-\mathrm{TiO}_{2}$ at $423 \mathrm{~K}$ (Table 2d).

\section{Discussion}

The transformation of the Ru active site is summarized in Scheme 1. The carbido Ru hexanuclear framework was retained at $290 \mathrm{~K}$ when cluster $\mathbf{1}$ was supported on weakly acidic metal

\section{SCHEME 1: Structure Transformation of the Ru Cluster Active Site Based on EXAFS ${ }^{a}$}

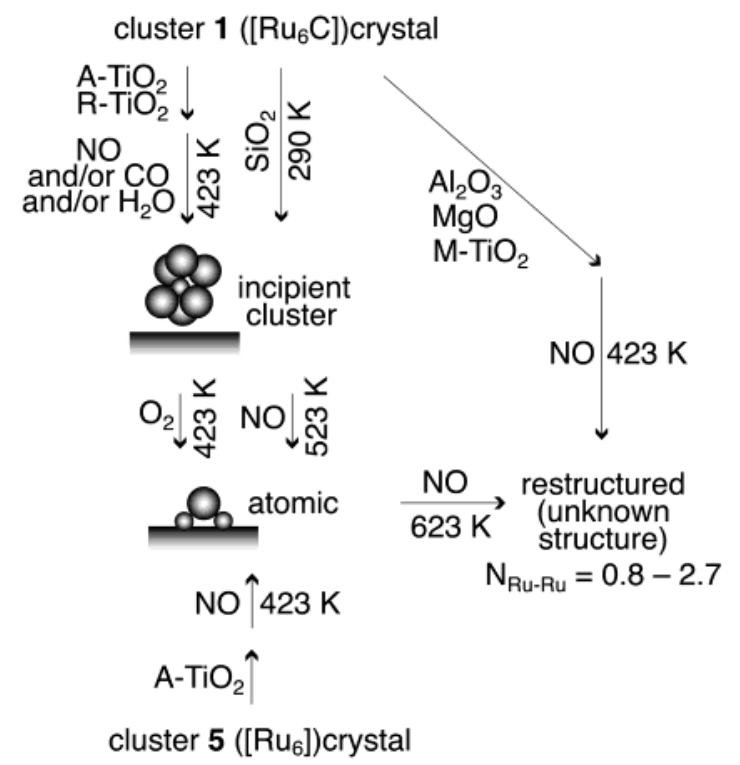

${ }^{a}$ The ligand is not drawn for clarity.

oxides such as $\mathrm{A}-\mathrm{TiO}_{2}, \mathrm{R}-\mathrm{TiO}_{2}$, and $\mathrm{SiO}_{2}$. On other supports ( $\mathrm{M}-\mathrm{TiO}_{2}, \mathrm{Al}_{2} \mathrm{O}_{3}$, and $\mathrm{MgO}$ ), the $\mathrm{Ru}_{6} \mathrm{C}$ framework appeared to split into smaller fragments on surface. Upon supporting carbonyl clusters on metal oxide, a general reaction we need to assume is the following water gas-shift type. ${ }^{22}$

$$
\begin{aligned}
& \mathrm{CO} \text { (ligand) }+\mathrm{OH}(\text { surface }) \rightarrow \\
& \left.\qquad \mathrm{CO}_{2}+\mathrm{H} \text { (ligand }\right)+\mathrm{O}-\mathrm{Ru}(\text { bond })
\end{aligned}
$$

In the cases that this reaction proceeds dominantly, loss of carbonyl ligands should lead to destabilization of the cluster framework. It has been reported that the reactivity of surface hydroxyl group of $\mathrm{MgO}$ and $\mathrm{Al}_{2} \mathrm{O}_{3}$ toward $\mathbf{1}$ as well as analogous anionic $\mathrm{Ru}$ carbonyl clusters is higher than those of $\mathrm{TiO}_{2}$ and $\mathrm{SiO}_{2}$ surfaces. 3,5

At $423 \mathrm{~K}$ in $\mathrm{NO}$, the $\mathrm{Ru}$ hexanuclear framework of $\left[\mathrm{Ru}_{6} \mathrm{C}\right] /$ $\mathrm{A}-\mathrm{TiO}_{2}$ was retained, whereas at $523 \mathrm{~K}$ in NO, the cleavage of $\mathrm{Ru}-\mathrm{Ru}$ bonds occurred and resulted in decomposition of the $\mathrm{Ru}$ hexanuclear structure. The effect of carbido carbon in stabilizing the $\mathrm{Ru}$ hexanuclear structure of $\left[\mathrm{Ru}_{6} \mathrm{C}(\mathrm{CO})_{16}\left(\mathrm{CH}_{3}\right)\right]^{-/}$ $\mathrm{A}-\mathrm{TiO}_{2}$ has already been noted either in $\mathrm{CO}+\mathrm{H}_{2}$ or in a vacuum at $523 \mathrm{~K}^{3}$ In a homogeneous system with saturated $\mathrm{NO}$ gas at room temperature, stepwise (partial) cleavage of $\mathrm{Ru}-$ $\mathrm{Ru}$ bonds in the $\mathrm{Ru}$ cluster begins to take place when more than three NO molecules coordinate to the cluster, transforming cluster 1 to 2 , and then to $3 .^{11}$ At higher temperatures of $423-$ $523 \mathrm{~K}$, nearly all the $\mathrm{Ru}-\mathrm{Ru}$ bonds of cluster 1 were cleaved by the effects of $\mathrm{NO}$ and precipitated in solution. In contrast, on the $\mathrm{A}-\mathrm{TiO}_{2}$ surface, a split single (or Ru ensemble consisted of less than six atoms) $\mathrm{Ru}$ atom was stabilized by the coordination of surface oxygen atoms (Scheme 1). When heated to $623 \mathrm{~K}$, the $\mathrm{Ru}-\mathrm{Ru}$ first coordination peak reappeared but the bond distance was shortened by $0.21 \AA$ (Figure $3 c$, Table 2f).

The overall trend was that the $\mathrm{Ru}$ hexanuclear framework became $\mathrm{Ru}$ ensemble units of fewer atom numbers (even single $\mathrm{Ru}$ atoms) and then the $\mathrm{Ru}$ ensemble was reorganized, consisting of fewer than approximately six $\mathrm{Ru}$ atoms when the temperature in NO was raised from 423 to $623 \mathrm{~K}$. This trend is understandable to consider the combination of two opposing factors: (1) 
the cleavage of $\mathrm{Ru}-\mathrm{Ru}$ bonds by NO and (2) the higher surface diffusion rate of metal atom (ensemble) at higher temperature. As the temperature was raised, the former factor reduced the $\mathrm{Ru}$ ensemble size whereas the latter factor inversely grew the ensemble size. Thus, the Ru ensemble size should reach the minimum at $523 \mathrm{~K}$.

The third and fourth factors are (3) the kind of support and (4) the presence/absence of carbido carbon inside the starting Ru cluster crystal framework. Relatively acidic support and the presence of carbido carbon were found to stabilize the $\mathrm{Ru}_{6}$ cluster framework. The effects of factors (1), (3) (basic support), and (4) (noncarbido cluster) were dominant in the case on $\left[\mathrm{Ru}_{6} \mathrm{C}\right] / \mathrm{M}-\mathrm{TiO}_{2}, \mathrm{Al}_{2} \mathrm{O}_{3}, \mathrm{MgO}$, and $\left[\mathrm{Ru}_{6}\right] / \mathrm{A}-\mathrm{TiO}_{2}$ at $423 \mathrm{~K}$.

Mononuclear surface $\mathrm{Ru}$ ion species was suggested as in Scheme 1 in the cases of $\left[\mathrm{Ru}_{6} \mathrm{C}\right] / \mathrm{A}-\mathrm{TiO}_{2}$ in $\mathrm{NO}+\mathrm{CO}+\mathrm{O}_{2}$ at $423 \mathrm{~K}$ (Table $2 \mathrm{~d}$ ), $\left[\mathrm{Ru}_{6} \mathrm{C}\right] / \mathrm{A}-\mathrm{TiO}_{2}$ in $\mathrm{NO}$ at $523 \mathrm{~K}(\mathrm{e})$, and noncarbido $\left[\mathrm{Ru}_{6}\right] / \mathrm{A}-\mathrm{TiO}_{2}$ in $\mathrm{NO}+\mathrm{CO}$ at $423 \mathrm{~K}$ (n). In the presence of $\mathrm{CO}$ gas, 0.6 of $\mathrm{Ru}-\mathrm{C}($ or $\mathrm{Ru}-\mathrm{N})$ and $\mathrm{R}(-\mathrm{C}-) \mathrm{O}$ \{or $\mathrm{Ru}(-\mathrm{N}-) \mathrm{O}$ \} coordination was observed (Table $2 \mathrm{~d}, \mathrm{n})$, but only the $\mathrm{Ru}-\mathrm{O}$ single peak was observed for $\left[\mathrm{Ru}_{6} \mathrm{C}\right] / \mathrm{A}-\mathrm{TiO}_{2}$ in $\mathrm{NO}$ at $523 \mathrm{~K}(\mathrm{e})$. Therefore, one $\mathrm{CO}$ molecule coordinated to one/two mononuclear surface $\mathrm{Ru}$ ion(s). Mononuclear ruthenium carbonyl species, $\mathrm{Ru}(\mathrm{CO})_{2}$ and $\mathrm{Ru}(\mathrm{CO})_{3}$ were reported in the case of $\left[\mathrm{Ru}\left(\mathrm{NH}_{3}\right)_{6}\right] / \mathrm{NaY}$ when heated at 393 $\mathrm{K} .{ }^{23}$ The $\mathrm{Ru}_{3}(\mathrm{CO})_{12}$ cluster supported in hydroxylated $\gamma-\mathrm{Al}_{2} \mathrm{O}_{3}$ was reported to transform into mononuclear $\left[\mathrm{Ru}(\mathrm{CO})_{2}\right]^{2+}$ species. ${ }^{24}$

The $\mathrm{Ru}$ metal surface of conventional $\mathrm{Ru} / \mathrm{TiO}_{2}$ catalysts is reported to be predominantly occupied by $\mathrm{NO}$ under $\mathrm{NO}+\mathrm{CO}$ gas. ${ }^{25}$ In the case of $\left[\mathrm{Ru}_{6} \mathrm{C}\right] / \mathrm{A}-\mathrm{TiO}_{2}$ (this study), the number of $\mathrm{CO}$ and NO ligands was estimated to be 12.1 and 1.9 per one $\mathrm{Ru}_{6} \mathrm{C}$ cluster unit on the basis of the EXAFS and GC analysis. The difference of adsorbent (ligand) ratio may be the reason that $\left[\mathrm{Ru}_{6}\right] / \mathrm{A}-\mathrm{TiO}_{2}$ exhibited a remarkably higher catalytic NO reduction rate at $423 \mathrm{~K}$ than the case of conventional $\mathrm{Ru} / \mathrm{TiO}_{2}$ catalyst (Table 1). The preferable $\mathrm{CO}$ adsorption was also reported in the case of $\left[\mathrm{Pt}_{12}(\mathrm{CO})_{24}\right]^{2-} / \mathrm{NaY}$ during the $\mathrm{NO}+$ CO reaction. ${ }^{8,9}$

Another plausible explanation of the higher NO reduction rate on $\left[\mathrm{Ru}_{6} \mathrm{C}\right] / \mathrm{A}-\mathrm{TiO}_{2}$ is the effect of bridging $\mathrm{CO}\left(\mu_{2}-\mathrm{CO}\right)$ on the $\mathrm{Ru}$ cluster site. On conventional $\mathrm{Ru}$ catalysts, only terminal (on-top) CO adsorption was observed by FT-IR (Fourier transformed infrared absorption spectroscopy). ${ }^{26}$ On the contrary, three bridging $\mathrm{CO}$ exist in the cluster $\mathbf{3}$, sharing a common $\mathrm{Ru}$ atom with a terminal $\mathrm{NO}$ ligand. A similar cluster structure was demonstrated in the case of $\left[\mathrm{Ru}_{6} \mathrm{C}\right] / \mathrm{A}-\mathrm{TiO}_{2}$ in $\mathrm{NO}$ at $423 \mathrm{~K}$ (Figure 1 and Table 2a).

In a practical point of view, $\mathrm{O}_{2}$ and/or $\mathrm{H}_{2} \mathrm{O}$ effects were considered. Structural transformation of the ruthenium cluster was observed in the presence of $\mathrm{O}_{2}$ (Scheme 1), resulting in the partial deactivation of catalytic $\mathrm{N}_{2}$ formation (Table 1). Water addition exhibited positive effects on this catalysis, however, the reason was not clarified by EXAFS study in this paper.

\section{Conclusions}

(1) The $\mathrm{Ru}$ hexanuclear framework was retained for $\left[\mathrm{Ru}_{6} \mathrm{C}\right] /$ $\mathrm{A}-\mathrm{TiO}_{2},\left[\mathrm{Ru}_{6} \mathrm{C}\right] / \mathrm{R}-\mathrm{TiO}_{2}$, and $\left[\mathrm{Ru}_{6} \mathrm{C}\right] / \mathrm{SiO}_{2}$ heated in $\mathrm{NO}$ at 423 $\mathrm{K}$. Stabilized $\mathrm{Ru}$ hexanuclear structure showed high NO conversion and high $\mathrm{N}_{2}$ selectivity in the $\mathrm{NO}+\mathrm{CO}$ reaction at $423 \mathrm{~K}$. The retained $\mathrm{Ru}_{6} \mathrm{C}$ core was found to be the best, designed surface site for the environmental NO removal.

(2) $\mathrm{The}_{\mathrm{Ru}}$ framework stabilized by the effects of carbido carbon and $\mathrm{TiO}_{2}$ surface split into smaller ensemble and finally single $\mathrm{Ru}$ atoms dispersed on $\mathrm{TiO}_{2}$ surface until $523 \mathrm{~K}$. This structural transformation was in the negative direction for the catalytic NO decomposition. The dispersed $\mathrm{Ru}$ atoms reorganized $\mathrm{Ru}$ ensemble consisted of less than six $\mathrm{Ru}$ atoms until $623 \mathrm{~K}$

(3) NO addition and basic support tend to cleave the $\mathrm{Ru}-$ $\mathrm{Ru}$ bonds. In contrast, carbido carbon stabilized the $\mathrm{Ru}_{6}$ framework from inside. Elevation of reaction temperature led to the aggregation of $\mathrm{Ru}$ atoms.

(4) The addition of $\mathrm{O}_{2}$ to the reaction mixture $\mathrm{NO}+\mathrm{CO}$ broke the $\mathrm{Ru}_{6} \mathrm{C}$ framework into atomically dispersed $\mathrm{Ru}$ atoms. The catalytic reactivity of $\mathrm{NO}$ decomposition over the $\mathrm{Ru}$ species was lower. No evident structural change was observed by the addition of $\mathrm{H}_{2} \mathrm{O}$.

Acknowledgment. The experiments were performed under the approval of the KEK-PF Program Review Committee (2001G092).

\section{References and Notes}

(1) Centi, G.; Ciambelli, P.; Perathoner, S.; Russo, P. Catal. Today 2002, 75 (1-4), 3-15.

(2) Gates, B. C. Chem. Rev. 1995, 95, 511-522.

(3) Izumi, Y.; Chihara, T.; Yamazaki, H.; Iwasawa, Y. J. Phys. Chem. 1994, 98, 594-602.

(4) Izumi, Y.; Iwasawa, Y. CHEMTECH 1994, 24 (7), 20-27.

(5) Izumi, Y.; Aika, K. J. Phys. Chem. 1995, 99, 10346-10353.

(6) Izumi, Y.; Kurakata, H.; Aika, K. J. Catal. 1998, 175, 236-244.

(7) Ali, A.; Alvarez, W.; Loughran, C. J.; Resasco, D. E. Appl. Catal., B 1997, 14, 13-22.

(8) Li, G.; Ichikawa, M.; Guo, X. React. Kinetics Catal. Lett., 1996, 59 (1), 75-86.

(9) Li, G.; Fujimoto, T.; Fukuoka, A.; Ichikawa, M. J. Chem. Soc., Chem. Commun. 1991, 1337-1339.

(10) Kobylinski, T. P.; Taylor, B. W. J. Catal. 1974, 33, 376-384.

(11) Wakatsuki, Y.; Chihara, T. Bull. Chem. Soc. Jpn. 1999, 72, 23572363.

(12) Chihara, T.; Sawamura, K.; Ikezawa, H.; Ogawa, H.; Wakatsuki, Y. Organometallics 1996, 15, 415-423.

(13) Chihara, T.; Tase, T.; Ogawa, H.; Wakatsuki, Y. Chem. Commun. 1999, 279-280.

(14) Ishiguro, A.; Liu, Y.; Nakajima, T.; Wakatsuki, Y. J. Catal. 2002, 206 (1), 159-164.

(15) Ishiguro, A.; Nakajima, T.; Iwata, T.; Fujita, M.; Minato, T.; Kiyotaki, F.; Izumi, Y.; Aika, K.; Uchida, M.; Kimoto, K.; Matsui, Y.; Wakatsuki, Y. Chem. Eur. J. 2002, 8 (14), 3260-3268.

(16) Hayward, C. T.; Shapley, J. R. Inorg. Chem. 1982, 21, 38163820

(17) Eady, C. R.; Jackson, P. F.; Johnson, B. F. G.; Lewis, J.; Malatesta, M. C.; McPartlin, M.; Nelson, W. J. H. J. Chem. Soc., Dalton Trans. 1980, 383-389.

(18) Yokoyama, T.; Hamamatsu, H.; Ohta, T. EXAFSH 2.1; The University of Tokyo.

(19) Based on X-ray crystallographic analysis of cluster 3. Unpublished work by T. Nakajima and Y. Wakatsuki.

(20) Binsted, N.; Cook, S. L.; Evans, J.; Greaves, G. N.; Price, R. J. Am. Chem. Soc. 1987, 109, 3669-3676.

(21) Wells, A. F. Structural Inorganic Chemistry, 5th ed.; Clarendon Press: Oxford, U.K., 1984.

(22) Basset, J. M.; Besson, B.; Choplin, A.; Thelier, A. Philos. Trans. R. Soc. London A 1982, 308, 115-124.

(23) Shen, J. G. C.; Liu, A. M.; Tanaka, T.; Ichikawa, M. J. Phys. Chem. $B$ 1998, 102, 7782-7792.

(24) Platero, E. E.; de Peralta, F. R.; Parra, J. B. J. Eur. Ceram. Soc.,1998, 18 (9), 1307-1312.

(25) Guglielminotti, E.; Boccuzzi, F. J. Chem. Soc., Faraday Trans. 1991, 87 (2), 337-343.

(26) Davydov, A. A.; Bell, A. T. J. Catal. 1977, 49 (3), 345-355. 